Jurnal Sistim Informasi dan Teknologi
https://jsisfotek.org/index.php

\title{
Sistem Pakar Menggunakan Metode Bayes untuk Analisis Penyakit Mulut pada Kucing
}

\author{
Fahrul Razi ${ }^{1 凶}$ \\ ${ }^{1}$ Independent Researcher \\ fahru1razi0398@gmai1.com
}

\begin{abstract}
The expert system using the Bayes method results in an analysis of oral diseases in cats. This expert system can be used by the general public to detect oral diseases in cats without having to come directly to the vet. Building an expert system software using the Bayes method to diagnose oral disease in cats equipped with solutions according to the indicated disease. The data that is processed in the expert system for detecting oral disease in cats is obtained from the results of interviews with animal disease specialists. The dataset used consists of 8 diseases. This expert system was built using the Bayes method. This expert system is made using a rule-based application and uses the PHP and MySQL programming languages. The results of testing this method are the types of diseases according to the symptoms entered by the user and solutions for disease prevention indicated by the system. This expert system is useful for the community to find out oral diseases in cats without having to come directly to a veterinarian. And can help doctors work in improving the accuracy of oral disease analysis in cats.
\end{abstract}

Keywords: Expert System, Bayes Method, Analysis, Cat Mouth Disease, Cats.

\begin{abstract}
Abstrak
Sistem pakar menggunakan metode Bayes mengahasilkan analisa tentang penyakit mulut pada kucing. Sistem pakar ini dapat digunakan oleh masyarakat umum untuk mendeteksi penyakit mulut pada kucing tanpa harus datang langsung ke dokter hewan. Membangun sebuah perangkat lunak system pakar menggunakan metode Bayes untuk mendiagnosa penyakit mulut pada kucing yang dilengkapi dengan solusi sesuai dengan penyakit yang terindikasi. Data yang dioloh dalam system pakar deteksi pneyakit mulut pada kucing ini di dapat dari hasil wawancara dengan pakar spesialis penyakit hewan. Dataset yang digunakan terdiri dari 8 penyakit. Sistem pakar ini dibangun dengan menggunakan metode Bayes. Sistem pakar ini dibuat menggunakan penerapan berbasis aturan / rule dan menggunakan bahasa pemograman PHP dan MySQL. Hasil dari pengujian terhadap metode ini adalah jenis penyakit sesuai dengan gejala yang di diinputkan oleh user dan solusi untuk pencegahan penyakit yang terindikasi oleh system. Sistem pakar ini berguna bagi masayaraakt untuk mengetahui penyakit mulut pada kucing tanpa harus datang langsung ke dokter spesialis hewan. Serta dapat membantu pekerjaan dokter dalam meningkatkan akurasi analisis penyakit mulut pada kucing.
\end{abstract}

Kata kunci: System Pakar,Metode Bayes,Analisa, Penakit Mulut Kucing, Kucing.

JSISFOTEK is licensed under a Creative Commons 4.0 International License. $(\mathrm{cc}) \mathrm{EY}$

\section{Pendahuluan}

Perkembangan ilmu pengetahuan terutama dibidang teknologi informasi semakin berkembang dan hampir semua bidang menggunakan perangkat komputer sebagai alat pendukung untuk mencari atau menghasilkan informasi[1]. Seiring dengan perkembangan komputer, maka peran dan kegunaan komputer semakin besar bahkan mendominasi kehidupan umat manusia sampai saat ini. Teknik untuk membuat komputer mampu mengolah pengetahuan salah satunya disebut teknik kecerdasan buatan [2]. Kecerdasan buatan atau Artificial Intelligence (AI) dapat membuat komputer melakukan hal-hal yang dilakukan layaknya seperti manusia. Dalam mengambilan keputusan manusia dapat menjadi komputer sebagai menetapkan keputusan [3].

Kucing adalah salah satu hewan yang populer dikalangan masyarakat dari berbagai kalangan dan usia, karena melihat dari bentuk fisiknya yang lucu dan tingkah yang menggemaskan merupakan salah satu alasan yang membuat banyak orang menyukai hewan peliharaan yang satu ini [4]. Kucing tidak lepas dari virus dan penyakit yang menyerangnya. Untuk itu, pemilik harus rajin meneliti perkembangan kondisi kucing agar jika terserang suatu penyakit atau diserang virus dapat segera di kenali sedini mungkin, banyak pemelihara yang tidak menyadari bahwa kucing yang mereka miliki mengidap suatu penyakit [5]. Gangguan respirasi tersebut biasanya disebabkan oleh virus, bakteri, parasit, jamur, dan benda asing [6].Kemajuan teknologi komputer saat ini dapat dimanfaatkan untuk mengatasi masalah ketersediaan dokter hewan tersebut, yaitu dengan cara mengembangkan sistem pakar agar pemelihara kucing yang tidak mengetahui tentang penyakit pada kucing dapat mendeteksi sedini mungkin penyakit yang diderita pada kucing serta mengetahui cara penanganannya[7]. 
Sistem pakar merupakan sistem yang berusaha mengadopsi pengetahuan manusia ke komputer [8]. Sistem ini bisa menyamai atau meniru kemampuan seorang pakar [9]. Sistem pakar mempunyai ciri-ciri diantaranya adanya fasilitas mengenai informasi yang dapat dipercayai, tidak sulit dimodifkasi, penggunaan tidak mengacu pada satu jenis komputer saja, dan memiliki tingkat adaptasi yang baik [10]. Dengan adanya Sistem Pakar yang akan dirancang, nantinya dapat dijadikan layanan konsultasi untuk dapat membantu dalam pendiagnosaan berdasarkan gejalagejala klinis yang ada [11].

Metode algoritma Bayes merupakan algoritma prediksi atau klasifikasi dengan metode statistik dan probabilitas [12]. Bayes merupakan sebuah konsep aturan yang dapat menghasilkan nilai kemungkinan serta memberikan informasi tambahan tentang nilai yang telah dihasilkan [13]. Metode bayes merupakan salah satu metode ketidakpastian dapat memberikan hasil diagnosa dengan nilai probabilitas [14]. Probabilitas bersyarat adalah probabilitas dari suatu peristiwa yang terjadi, mengingat bahwa itu memiliki beberapa hubungan dengan satu atau lebih peristiwa lainnya [15]. Maka akan dilakukan penelitian dalam memanfaatkan kecerdasan buatan dengan menggunakan metode Bayes yang bertujuan untuk mengalisis pemyakit mulut pada kucing

\section{Metodologi Penelitian}

Metode dalam penelitian ini disusun melalui sebuah kerangka kerja terleboh dahulu [16]. Metode penelitian merupakan prosedur dan teknik penelitian [17]. Adapun kerangka kerja penelitian yang digunakan seperti pada Gambar 1.

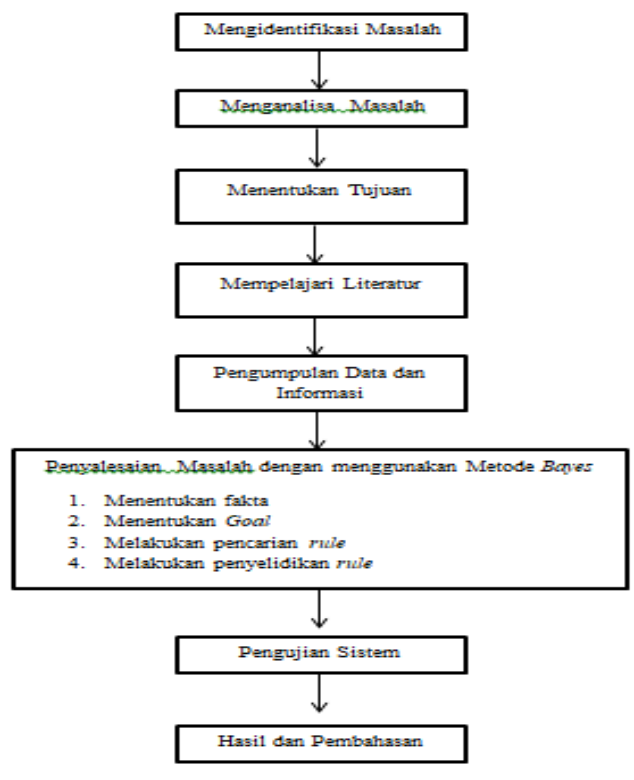

Gambar 1. Kerangka Kerja Penelitan

Berdasarkan gambar kerangka kerja penelitian di atas dapat dijelaskan sebagai berikut:

\subsection{Mengidentifikasi Masalah}

Untuk memberikan penjelasan mengenai penelitian yang akan diteliti, temtukan terlebih dahulu masalah yang akan diteliti. Menentukan masalah pada penelitian merupakan langkah pertama yang harus dilakukan.

\subsection{Menganalisa Masalah}

Menganalisa masalah ini merupakan suatu langkah yang dilakukan untuk alur selanjutnya dari penelitian, sehingga dalam melakukan penelitian dapat memahami permasalahan yang ada.

\subsection{Menentukan Tujuan}

Tujuan penelitian dapat dikatakan suatu hasil yang diharapkan ketika penelitian telah selesai dikerjakan, dan sesuatu yang akan dicapai dalam melakukan penelitian

\subsection{Mempelajari Literatur}

Berdasarkan tujuan yang ingin dicapai, maka dibutuhkan kajian literatur sesuai dengan tujuan penelitian. Sumber dari literatur ini dapat berasal dari artikel, jurnal ilmiah mengenai metode Bayes, serta referensi-referensi yang berhubungan dengan penelitian.

\subsection{Pengumpulan Data dan Informasi}

Tujuan dari pengumpulan data adalah untuk mendapatkan suatu informasi dari data-data yang dibutuhkan untuk penelitian agar mencapai tujuan yang diharapkan. Pengumpulan data dengan melakukan wawancara langsung dengan pakar mengenai hal-hal yang berhubungan dengan objek penelitian. Pengumpulan data ini merupakan sebuah teknik yang dilakukan untuk memperoleh data yang ideal, dilakukan secara langsung melalui penelitian lapangan.

2,6, Penyelesaian Masalah Dengan Menggunakan Metode Bayes

Dilakukan perancangan dan analisa pada permasalahan yang ada sesuai dengan data-data yang sudah terkumpul dengan langkah-langkah yang terdapat pada metode Bayes, sehingga permasalahan-permasalahan tersebut dapat menemukan solusinya. Pada tahap ini juga disertakan langkah-langkah yang harus dikerjakan, antara lain :

\section{a. Menentukan Fakta}

Pada penyelesaian masalah menggunakan metode Bayes ini dilakukan dengan menemukan fakta-fakta. Fakta merupakan bukti-bukti yang berhubungan dengan goal yang akan dicari.

b.Menentukan Goal

Jurnal Sistim Informasi dan Teknologi - Vol. 4 No. 2 (2022) 52-57 
Dalam menentukan Goal diawali dengan penemuan fakta-fakta pendukung kemudian dilakukannya proses kerja sesuai dengan metode Bayes.

\section{c.Melakukan Pencarian Rule}

Pada metode Bayes akan dilakukan pencarian rule-rule yang terdapat pada basis data. Proses pencarian memakai bukti agar menunjang suatu rule yang digunakan sebagai sebuah data yang akan dimasukkan kedalam system.

\section{d.Melakukan Penyelidikan Rule}

Pada saat melakukan penyelidikan rule nilai pada atribut harus sinkron dengan data yang sudah didapat pada saat wawancara dengan pakar.

\subsection{Pengujian Sistem}

Tahap ini dilakukan untuk memberikan kepastian terhadap Sistem Pakar yang sudah dibangun apakah sudah sampai pada tujuan yang diharapkan serta sudahkah bisa dilakukan implementasi terhadap pengguna.

\subsection{Hasil dan Pembahasan.}

Pada tahap hasil, akan diperlihatkan suatu hal yang sukses dikerjakan oleh sistem yang dibangun. Sedangkan pada tahap pembahasan, akan diperlihatkan apakah hasil yang diperoleh sistem cocok dengan hasil yang diinginkan dari analisa yang sudah dilakukan.

\section{Hasil dan Pembahasan}

Data yang diperoleh dari hasil wawancara dengan pakar berupa data penyakit, gejala, serta nilai probabilitas masing-masing gejala sesuai dengan penyakit yang bersangkutan. Beberapa jenis penyakit mulut kucing dapat dilihat pada Tabel 1.

Tabel 1. Pennyakit mulut kucing

\begin{tabular}{ll}
\hline Product & Penyakit \\
\hline P01 & Sariawan (Stokomatitis) \\
P02 & Mulut Kerng (xerostomia) \\
P03 & Scabies Mulut \\
P04 & Tumor Mulut \\
P05 & Kanker Mulut \\
\hline
\end{tabular}

Selanjutnya akan ditunjukkan beberapa gejala penyakit mulut pada kucing seperti yang terlihat pada Tabel 2.
Tabel 2. Gejala penyakit mulut kucing.

\begin{tabular}{ll}
\hline Kode Gejala & Penyakit \\
\hline G01 & Kesulitan dalam mencerna makanan \\
G02 & Mengurangi nafsu makan \\
G04 & Infeksi pada mulut kucing \\
G05 & Berkurangnya imunitas kucing \\
G06 & Produksi air liur berkurang \\
G07 & Gusi dan selaput lendir kering \\
G08 & Dehidrasi \\
G09 & Demam \\
G10 & Anestesi \\
G11 & Adanya kerak pada mulut kucing \\
G12 & Adanya pembengkakan \\
G13 & Gusi merah \\
G14 & Air liur menetes \\
G15 & Penurunan berat badan \\
G16 & Mulut kucing berbau \\
G17 & Kehilangan gigi mendadak \\
G18 & Sering menggertakkan gigi \\
G19 & Sering menggaruk di area sekitar mulut \\
G20 & Darah keluar dari mulut \\
G21 & Kudis hitam di area mulut \\
\hline
\end{tabular}

Berikut adalah nilai probabilitas gejala-gejala yang terkena penyakit mulut pada kucing berdasarkan pengalaman seorang pakar yang telah menangani penyakit mulut pada kucing. Nilai probabilitas dapat dilihat pada Tabel 3.

Tabel 3. Nilai probabilitas gejala

\begin{tabular}{lccccc}
\hline Kode & P01 & P02 & P03 & P04 & P05 \\
\hline G01 & 0.627 & - & 0,595 & - & - \\
G02 & 0,549 & - & 0,198 & 0,820 & 0.103 \\
G03 & 0,157 & - & 0,198 & - & - \\
G04 & 0,549 & - & - & - & - \\
G05 & 0,706 & 0,176 & - & - & - \\
G06 & - & 0,471 & - & - & - \\
G07 & - & 0,078 & - & - & - \\
G08 & - & 0,099 & - & - & - \\
G09 & - & 0,496 & - & - & - \\
G10 & - & - & 0,099 & - & - \\
G11 & - & - & 0,198 & 0,410 & 0,718 \\
G12 & 0,392 & - & - & 0,513 & - \\
G13 & - & - & - & - & 0,107 \\
G14 & - & - & - & 0,718 & 0,214 \\
G15 & 0,078 & - & - & - & 0,536 \\
G16 & - & - & - & - & 0,964 \\
G17 & 0,157 & - & - & - & - \\
G18 & - & - & 0,298 & - & - \\
G19 & - & - & - & - & 0,964 \\
G20 & - & - & 0,513 & - & - \\
G21 & - & - & - & 0,103 & - \\
\hline
\end{tabular}

Setiap penyakit memiliki penanganan atau solusi agar kucing peliaraan tidak terserang penyakit mulut. Dijelaskan pada Tabel 4. 
Tabel 4. Solusi penyakit mulut kucing

\begin{tabular}{ll}
\hline Product & Solusi \\
& -Menjaga kebersian mulut kucing \\
& -Menganti asupan makan kucing dengan \\
P01 & -Pekanan basah \\
& -Pemberian obat-obatan \\
& -Mencabut gigi di sekitar bagian yang meradang \\
& -Melakukan konsultasi dengan dokter hewan \\
P02 & -Memberi makanan basah \\
& -Lebih sering memberi minum kucing \\
& -Pemberian obat-obatan \\
P03 & -Pisakan lucing yang terinfeksi dengan yang lain \\
& -Hindari tempat perawtan kucing yang buruk \\
& -Cuci alat perawatan kucing \\
P04 & -Suntik scabies kucing \\
& -Melakukan tindakan operasi untuk pengangkatan \\
P05 & -Menjaga keseatan mulut kucing \\
& -Melakukan pendeteksian sedini mungkin \\
& -Melakukan pengobatan pada kucing \\
& -Melakukan operasi untuk pengangkatan kanker. \\
\hline
\end{tabular}

Secara umum metode Bayes dinyatakan dalam persamaan perhihtungan manual untuk melakukan penalaran disajikan pada Persamaan (1).

$$
P(H i \mid E)=\frac{P(E \mid H i) X P(H i)}{\sum_{k=1}^{n} P(E \mid H k) X P(H k)}
$$

Dimana nilai $\mathrm{P}(\mathrm{Hi} \mid \mathrm{E})$ adalah Probabilitas hipotesa $\mathrm{Hi}$ terjadi jika evidence $\mathrm{E}$ terjadi. $\mathrm{P}(\mathrm{E} \mid \mathrm{Hi})$ adalah probabilitas munculnya evidence $\mathrm{E}$ jika hipotesa $\mathrm{Hi}$ terjadi. $\mathrm{P}(\mathrm{Hi}) \quad$ adalah probabilitas hipotesa $\mathrm{H}$ tanpa memandang evidence apapun dan $\mathrm{n}$ adalah jumlah hipotesa yang terjadi.

Contoh kasus dari penyakit mulut pada kucing dengan menjawab beberapa pertanyaan, dan di dapatkan gejala G01, G02, G03, G06, G07, G11, G13, G14, G15, G19 dan G21.

Mendefenisikan Terlebih dahulu nilai probabilitas dari tiap evidence untuk tiap hipotesis berdasarkan data sampel yang ada menggunakan rumus probabilitas bayes.
$\mathrm{G} 01=\mathrm{P}(\mathrm{E} / \mathrm{H} 1)=0,627$
$\mathrm{G} 02=\mathrm{P}(\mathrm{E} / \mathrm{H} 1)=0,549$
$\mathrm{G} 03=\mathrm{P}(\mathrm{E} / \mathrm{H} 1)=0,157$
$\mathrm{G} 15=\mathrm{P}(\mathrm{E} / \mathrm{H} 1)=0,078$
a. $\mathrm{P} 01=$ Sariawan (Stokomatitis)
b. $\mathrm{P} 02=$ Mulut kering (Xerostomia $)$
$\mathrm{G} 06=\mathrm{P}(\mathrm{E} / \mathrm{H} 2)=0,471$
$\mathrm{G} 07=\mathrm{P}(\mathrm{E} / \mathrm{H} 2)=0,078$
c. $\mathrm{P} 03=$ Scabies Mulut
$\mathrm{G} 01=\mathrm{P}(\mathrm{E} / \mathrm{H} 3)=0,595$
$\mathrm{G} 02=\mathrm{P}(\mathrm{E} / \mathrm{H} 3)=0,198$
$\mathrm{G} 03=\mathrm{P}(\mathrm{E} / \mathrm{H} 3)=0,198$
$\mathrm{G} 11=\mathrm{P}(\mathrm{E} / \mathrm{H} 3)=0,198$
d. $\mathrm{P} 04=$ Tumor Mulut
$\mathrm{G} 02=\mathrm{P}(\mathrm{E} / \mathrm{H} 4)=0,820$
$\mathrm{G} 11=\mathrm{P}(\mathrm{E} / \mathrm{H} 4)=0,410$
$\mathrm{G} 14=\mathrm{P}(\mathrm{E} / \mathrm{H} 4)=0,718$
$\mathrm{G} 21=\mathrm{P}(\mathrm{E} / \mathrm{H} 4)=0,103$
e. $\mathrm{P} 05=$ Kanker Mulut
$\mathrm{G} 02=\mathrm{P}(\mathrm{E} / \mathrm{H} 5)=0,103$

$$
\begin{aligned}
& \mathrm{G} 11=\mathrm{P}(\mathrm{E} / \mathrm{H} 5)=0,718 \\
& \mathrm{G} 13=\mathrm{P}(\mathrm{E} / \mathrm{H} 5)=0,107 \\
& \mathrm{G} 14=\mathrm{P}(\mathrm{E} / \mathrm{H} 5)=0,214 \\
& \mathrm{G} 15=\mathrm{P}(\mathrm{E} / \mathrm{H} 5)=0,536 \\
& \mathrm{G} 19=\mathrm{P}(\mathrm{E} / \mathrm{H} 5)=0,964
\end{aligned}
$$

Kemudian menjumlahkan nilai probabilitas dari tiap evidence untuk masing-masing hipotesis berdasarkan data sampel.

1. $\mathrm{P} 01=\mathrm{G} 01+\mathrm{G} 02+\mathrm{G} 03+\mathrm{G} 15=0,627+0,549+$ $0,157+0,078=1,411$

2. $\mathrm{P} 02=\mathrm{G} 06+\mathrm{G} 07=0,471+0,078=0,549$

3. $\mathrm{P} 03=\mathrm{G} 01+\mathrm{G} 02+\mathrm{G} 03+\mathrm{G} 11=0,595+0,198+$ $0,198+0,198=1,189$

4. $\mathrm{P} 04=\mathrm{G} 02+\mathrm{G} 11+\mathrm{G} 14+\mathrm{G} 21=0,820+0,410+$ $0,718+0,103=2,051$

5. $\mathrm{P} 05=\mathrm{G} 02 \mathrm{~V}+\mathrm{G} 11+\mathrm{G} 13+\mathrm{G} 14+\mathrm{G} 15+\mathrm{G} 19=$ $0,103+0,718+0,107+0,214+0,536+0,964=$ 2,642

Selanjutnya mencari nilai probabilitas hipotesis $\mathrm{H}$ tanpa memandang evidence apapun bagi masingmasing.

a. $\mathrm{P} 01=$ Sariawan (Stokomatitis)

$\mathrm{G} 01=\mathrm{P}(\mathrm{H} 1)=0,627 / 1,411=0,444$

$\mathrm{G} 02=\mathrm{P}(\mathrm{H} 1)=0,549 / 1,411=0,389$

$\mathrm{G} 03=\mathrm{P}(\mathrm{H} 1)=0,157 / 1,411=0,111$

$\mathrm{G} 15=\mathrm{P}(\mathrm{H} 1)=0,078 / 1,411=0,055$

b. $\mathrm{P} 02$ = Mulut kering (Xerostomia)

$\mathrm{G} 06=\mathrm{P}(\mathrm{H} 2)=0,471 / 0,549=0,857$

$\mathrm{G} 07=\mathrm{P}(\mathrm{H} 2)=0,078 / 0,549=0,142$

c. $\mathrm{P} 03=$ Scabies Mulut

$\mathrm{G} 01=\mathrm{P}(\mathrm{H} 3)=0,595 / 1,189=0,500$

$\mathrm{G} 02=\mathrm{P}(\mathrm{H} 3)=0,198 / 1,189=0,166$

$\mathrm{G} 03=\mathrm{P}(\mathrm{H} 3)=0,198 / 1,189=0,166$

$\mathrm{G} 11=\mathrm{P}(\mathrm{H} 3)=0,198 / 1,189=0,166$

d. $\mathrm{P} 04=$ Tumor Mulut

$\mathrm{G} 02=\mathrm{P}(\mathrm{H} 4)=0,820 / 2,051=0,399$

$\mathrm{G} 11=\mathrm{P}(\mathrm{H} 4)=0,410 / 2,051=0,199$

$\mathrm{G} 14=\mathrm{P}(\mathrm{H} 4)=0,718 / 2,051=0,350$

$\mathrm{G} 21=\mathrm{P}(\mathrm{H} 4)=0,103 / 2,051=0,050$

e. $\mathrm{P} 05=$ Kanker Mulut

$\mathrm{G} 02=\mathrm{P}(\mathrm{H} 5)=0,103 / 2,642=0,039$

$\mathrm{G} 11=\mathrm{P}(\mathrm{H} 5)=0,718 / 2,642=0,272$

$\mathrm{G} 13=\mathrm{P}(\mathrm{H} 5)=0,107 / 2,642=0,040$

$\mathrm{G} 14=\mathrm{P}(\mathrm{H} 5)=0,214 / 2,642=0,080$

$\mathrm{G} 15=\mathrm{P}(\mathrm{H} 5)=0,536 / 2,642=0,203$

$\mathrm{G} 19=\mathrm{P}(\mathrm{H} 5)=0,964 / 2,642=0,365$

Kemudian mencari nilai probabilitas hipotesis memandang evidence dengan cara mengalikan nilai probabilitas hipotesis tanpa memandang evidence dan menjumlahkan hasil perkalian bagi masing-masing hipotesis.

a. $\mathrm{P} 01=(0,627 * 0,444)+(0,549 * 0,389)+(0,157 *$ $0,111)+(0,078 * 0,055)=0,278+0,213+0,017+$ $0,004=0,512$

b. $\mathrm{P} 02=(0,471 * 0,857)+(0,078 * 0,142)=0,403+$ $0,011=0,414$ 
c. $\mathrm{P} 03=(0,595 * 0,500)+(0,198 * 0166)+(0,198 *$ $0166)+(0,198 * 0166)=0,297+0,032+0,032+$ $0,032=0,393$

d. $\mathrm{P} 04=(0,820 * 0,399)+(0,410 * 0,199)+(0,718+$ $0,350)+(0,103 * 0,050)=0,327+0,081+0,251$ $+0,005=0,664$

e. $\mathrm{P} 05=(0,103 * 0,039)+(0,718 * 0,272)+(0,107 *$ $0,040)+(0,214 * 0,080)+(0,536 * 0,203)+(0,964$ $* 0,365)=0,004+0,195+0,004+0,017+0,108+$ $0,351=0,679$

Langkah selanjutnya mencari nilai $\mathrm{P}(\mathrm{Hi} \mid \mathrm{E})$ atau probabilitas hipotesis Hi benar jika diberikan evidence e.

a. $\quad$ P01 $=$ Sariawan (Stokomatitis)

$\mathrm{G} 01=0,627 * 0,444 / 0,512=0,542$

$\mathrm{G} 02=0,549 * 0,389 / 0,512=0,416$

$\mathrm{G} 03=0,157 * 0,111 / 0,512=0,033$

$\mathrm{G} 15=0,078 * 0,055 / 0,512=0,007$

b. $\mathrm{P} 02=$ Mulut kering (Xerostomia)

$\mathrm{G} 06=0,471 * 0,857 / 0,414=0,097$

$\mathrm{G} 07=0,078 * 0,142 / 0,414=0,026$

c. $\mathrm{P} 03=$ Scabies Mulut

$\mathrm{G} 01=0,595 * 0,500 / 0,393=0,755$

$\mathrm{G} 02=0,198 * 0,166 / 0,393=0,081$

$\mathrm{G} 03=0,198 * 0,166 / 0,393=0,081$

$\mathrm{G} 11=0,198 * 0,166 / 0,393=0,081$

d. $\mathrm{P} 04=$ Tumor Mulut

$\mathrm{G} 02=0,820 * 0,399 / 0,664=0,492$

$\mathrm{G} 11=0,410 * 0,199 / 0,, 664=0,121$

$\mathrm{G} 14=0,718 * 0,350 / 0,, 664=0,378$

$\mathrm{G} 21=0,103 * 0,050 / 0,, 664=0,007$

e. $\mathrm{P} 05=$ Kanker Mulut

$\mathrm{G} 02=0,103 * 0,039 / 0,679=0,005$

$\mathrm{G} 11=0,718 * 0,272 / 0,679=0,287$

$\mathrm{G} 13=0,107 * 0,040 / 0,679=0,005$

$\mathrm{G} 14=0,214 * 0,080 / 0,679=0,025$

$\mathrm{G} 15=0,536 * 0,203 / 0,679=0,159$

$\mathrm{G} 19=0,964 * 0,365 / 0,679=0,516$

Selanjutnya mengalikan nilai probabilitas evidence awal dengan nilai hipotesis $\mathrm{H}$ benar jika diberikan evidence $\mathrm{E}$ dan menjumlahkan hasil perkalian.

a. $\mathrm{P} 01=(0,627 * 0,542)+(0,549 * 0,416)+(0,111 *$ $0,033)+(0,078 * 0,007)=0,339+0,228+0,005+$ $0,0005=0,572$

b. $\mathrm{P} 02=(0,471 * 0,097)+(0,078 * 0,026)=0,458+$ $0,007=0,460$

c. $\mathrm{P} 03=(0,595 * 0,755)+(0,198 * 0,081)+(0,198 *$ $0,081)+(0,198 * 0,081)=0,449+0,016+0,016+$ $0,016=0,497$

d. $\mathrm{P} 04=(0,820 * 0,492)+(0,410 * 0,121)+(0,718+$ $0,378)+(0,103 * 0,007)=0,403+0,049+0,271+$ $0,0007=0,765$

e. $\mathrm{P} 05=(0,103 * 0,005)+(0,718 * 0,287)+(0,107+$ $0,005)+(0,214+0,025)+(0,536+0,159)+$ $(0,964 * 0,516)=0,0005+0,206+0,0005+0,005$ $+0,085+0,497=0,794$
Maka persentase perhitungan penyakit mulut pada kucing sebagai berikut:

a. $\quad \mathrm{P} 01=$ Saraiwan (Stokomstitis)

$$
0,572 * 100 \%=57,2 \%
$$

b. $\mathrm{P} 02=$ Mulut kering (Xerostomia)

$0,460 * 100 \%=46 \%$

c. $\mathrm{P} 03=$ Scabies Mulut

$0,497 * 100 \%=49,7 \%$

d. $\mathrm{P} 04=$ Tumor Mulut

$0,765 * 100 \%=76,5 \%$

e. P05 = Kanker Mulut

$0,794 * 100 \%=79,4 \%$

Dari kesimpulan perhitungan diatas,didapatkan bawa penyakit mulut yang di alami kucing adalah Kanker mulut dengan persentase $79,4 \%$.

\section{Kesimpulan}

Dari pembahasan permasalahan diatas, maka dapat diambil kesimpulan bahwa sistem pakar yang telah dibuat dapat melakukan penulusuran gejala dan penyakit berdasarkan penulusuran jawaban atas pertanyaan-pertanyaan yang telah diberikan melalui interkasi dengan sistem. Dengan adanya aplikasi sistem pakar ini dapat membantu masyarakat untuk mengetahui gejala dan penyakit yang diderita pada mulut kucing. Sistem pakar yang dibuat berbasiskan web sehingga dapat diakses dimanapun, kapanpun, serta dapat mempermuda user dalam mendiagnosa penyakit mulut pada kucing sedini mungkin.

\section{Daftar Rujukan}

[1]. Takariyanti, D. N. R., Batan, I. W., \& Erawan, I. G. M. K. Laporan Kasus: Rhinitis Unilateral pada Kucing Lokal yang Mengalami Langit-langit Mulut Bercelah (Cleft Palate). DOI: 10.19087/imv.2020.9.6.9.1036

[2]. Nugroho, F. A., Solikin, A. F., Anggraini, M. D., \& Kusrini, K. (2021). Sistem Pakar Diagnosa Virus Corona Dengan Metode Naïve Bayes. Jurnal Teknologi Informasi dan Komunikasi (TIKomSiN), 9(1), 81-88.DOI: http://dx.doi.org/10.30646/tikomsin.v9i1.553

[3]. Sagat, N. A., \& Purnomo, A. S. (2021). Sistem Pakar Diagnosa Penyakit Mata Menggunakan Metode Teorema Bayes. Jurnal Pendidikan dan Teknologi Indonesia, 1(8), 329-337. DOI: https://doi.org/10.52436/1.jpti.73

[4]. Tambak, R. R., Purnama, I., \& Hasibuan, E. R. (2021). Sistem Pakar Untuk Mendiagnosis Penyakit Tubercolosis Mengunakan Metode Bayes Pada Puskesmas Petumbukan. Jurnal Teknik Informatika UNIKA Santo Thomas, 45-52. DOI : https://doi.org/10.54367/jtiust.v6i1.1284

[5]. Sukma, I., \& Petrus, M. (2020). Sistem Pakar Penyakit Kucing Menggunakan Metode Forward Chaining Berbasis Web. Simtek: jurnal sistem informasi dan teknik komputer, 5(1), 5258. DOI: https://doi.org/10.51876/simtek.v5i1.73

[6]. Sidauruk, A., \& Abdullah, A. (2020). Sistem Pakar Penentuan Makanan Pendamping Air Susu Ibu Menggunakan Metode Min Max Dan Naïve Bayes. Sistemasi: Jurnal Sistem Informasi, 9(1), 191-200. DOI: https://doi.org/10.32520/stmsi.v9i1.587

[7]. Rachman, R. (2020). Sistem Pakar Deteksi Penyakit Refraksi Mata Dengan Metode Teorema Bayes Berbasis Web. Jurnal

Jurnal Sistim Informasi dan Teknologi - Vol . 4 No. 2 (2022) 52-57 
Informatika,

$7(1)$

$68-76$

https://doi.org/10.31294/ji.v7i1.7267

[8]. Pratama, E. B., \& Hendini, A. (2019). Sistem Pakar Diagnosa Penyakit Kulit Pada Kucing Berbasis Web Menggunakan Metode Decision Tree. Sistemasi: Jurnal Sistem Informasi, 8(2), 254-264. DOI: https://doi.org/10.32520/stmsi.v8i2.459.

[9]. Hadi, F., \& Diana, Y. (2019). Sistem Pakar Diagnosa Penyakit Gigi dengan Metode Bayes. Sains dan Teknologi Informasi, 5(2), 44-51. DOI: 10.33372/stn.v5i2.513

[10]. Syahputra, T., \& Maya, W. R. (2019). Implementasi Sistem Pakar Untuk Mengidentifikasi Pecandu Narkoba Menggunakan Metode Teorema Bayes. Jurnal SAINTIKOM (Jurnal Sains Manajemen Informatika dan Komputer), 18(2), 111-118. DOI: https://doi.org/10.53513/jis.v18i2.149

[11]. Rusdiyanto, R. (2018). Sistem Pakar Diagnosa Penyakit Akibat Gigitan Nyamuk Dengan Metode Bayes Berbasis Web. JUTIM (Jurnal Teknik Informatika Musirawas), 3(1), 30-40. DOI 10.32767/JUTIM.V3I1.278.

[12]. Widiyawati, C., \& Imron, M. (2018). Sistem Pakar Diagnosa Penyakit Pada Kucing Menggunakan Metode Naive Bayes Classifier. Techno. Com, 17(2), 134-144. DOI: https://doi.org/10.33633/tc.v17i2.1625
[13]. Nurdiawan, O., \& Pangestu, L. (2018). Penerapan Sistem Pakar dalam Upaya Meminimalisir Resiko Penularan Penyakit Kucing. InfoTekJar: Jurnal Nasional Informatika dan Teknologi Jaringan, 3(1), 65-73. DOI: https://doi.org/10.30743/infotekjar.v3i1.532

[14]. Ningsih, C., Sitio, A. S., \& Gea, A. (2018). Sistem Pakar Mendiagnosa Penyakit Jantung Dengan Menggunakan Teorema Bayes. Jurnal Armada Informatika 2(2):155-164. DOI:10.36520/jai.v2i2.27

[15]. Simanjuntak, P. M. S. (2018). Sistem Pakar Diagnosa Penyakit Gigi dan Mulut Menggunakan Metode Naive Bayes-Weighted Product (Doctoral dissertation, Universitas Brawijaya). DOI http://repository.ub.ac.id/id/eprint/13821

[16]. Ramadhan, P. S. (2018). Sistem Pakar Pendiagnosaan Dermatitis Imun Menggunakan Teorema Bayes. InfoTekJar: Jurnal Nasional Informatika dan Teknologi Jaringan, 3(1), 4348. DOI: https://doi.org/10.30743/infotekjar.v3i1.643

[17]. Ramadhan, P. S. (2018). Sistem Pakar Pendeteksian Varicella Simplex Dengan Menggunakan Teorema Bayes. JURIKOM (Jurnal Riset Komputer), 5(5), 454-459. DOI: http://dx.doi.org/10.30865/jurikom.v5i5.874 